\title{
Association between UGT1A1*28 Gene Polymorphism and Severe Neutropenia due to Colorectal Cancer Treatment with Irinotecan: Evidence Based on Meta-Analysis
}

\section{Associação entre o polimorfismo do gene UGT1A1*28 e a neutropenia severa decorrente do tratamento do câncer colorretal com irinotecano: evidências baseadas em meta-análise}

Tayná Aparecida de Oliveira Santos ${ }^{1}$ Jacqueline Andréia Bernardes Leão-Cordeiro ${ }^{2}$ (1) Daiane de Oliveira Cunha ${ }^{30}$ Cesar Augusto Sam Tiago Vilanova-Costa ${ }^{4}$ Xisto Sena Passos ${ }^{10}$ Antonio Márcio Teodoro Cordeiro Silva ${ }^{3,5}$ ()

\footnotetext{
${ }^{1}$ Biomedicine Course, Universidade Paulista (UNIP), Goiânia, GO, Brazil

2 Faculdade de Enfermagem (FEN), Universidade Federal de Goiás (UFG), Goiânia, GO, Brazil

3 Programa de Pós-Graduação, Mestrado em Ciências Ambientais e Saúde (MCAS), Pontifícia Universidade Católica de Goiás (PUC Goiás), Goiânia, GO, Brazil

4 Tumoral Biology and Oncogenetics Laboratory, Hospital Araújo Jorge, Goiânia, GO, Brazil

${ }^{5}$ Medicine Course, Escola de Ciências Médicas, Farmacêuticas e Bimomédicas (EMFB), Pontifícia Universidade Católica de Goiás (PUC Goiás), Goiânia, GO, Brazil
}

\begin{abstract}
Address for correspondence Antonio Márcio Teodoro Cordeiro Silva, D.Sc., Medicine Course, Escola de Ciências Médicas, Farmacêuticas e Biomédicas. Pontifícia Universidade Católica de Goiás (PUC Goiás), Avenida Universitária 1.440, Setor Universitário, Campus 1, Área 4, Goiânia, Goiás, 74605-010, Brazil (e-mail: marciocmed@gmail.com).
\end{abstract}

J Coloproctol 2021;41(2):188-192.
Abstract
Objective The present study aimed to evaluate the relationship between UGT1A ${ }^{*} 28$ gene polymorphism and the prevalence of neutropenia in patients with colorectal cancer treated with irinotecan.
Method Thirteen studies were included. These papers were selected from the Virtual Health Library, Scientific Electronic Library Online, International Health Sciences Literature and PubMed, and their data were collected and evaluated using the BioEstat 5.3 software (BioEstat, Belém, PA, Brazil).
Results Three genotypes were analyzed, namely $6 / 6$ (wild type), 6/7, and $7 / 7$. In total, 2,146 patients were included in the present study; of these, $55.6 \%(n=1,193)$ had $6 / 6$

\section{Keywords}
- neutropenia
- colorectal cancer
- polymorphisms genotype, $37.3 \%(n=801)$ were heterozygous $(6 / 7)$, and $7.1 \%(n=152)$ had the $7 / 7$ genotype. A total of $1,672(77.9 \%)$ patients displayed mild neutropenia, whereas 474 (22.1\%) had severe neutropenia. When contrasting the $6 / 7$ and $7 / 7$ genotypes with the $6 / 6$ genotype using statistical tests for meta-analysis, patients with the 7 allele, either
received
May 21, 2020
accepted
August 11, 2020
DOI https://doi.org/
10.1055/s-0041-1725047. ISSN 2237-9363.

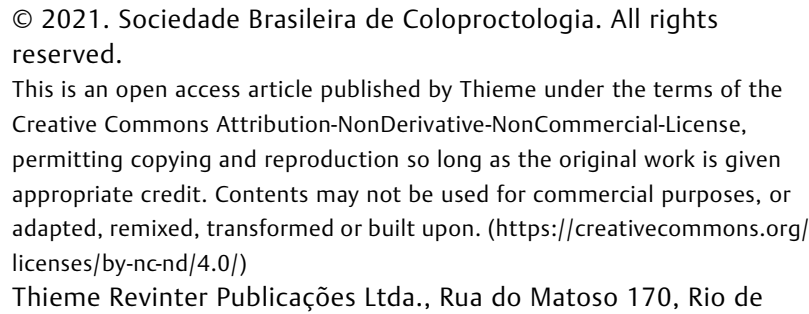

(C) 2021. Sociedade Brasileira de Coloproctologia. All rights reserved.

This is an open access article published by Thieme under the terms of the Creative Commons Attribution-NonDerivative-NonCommercial-License, permitting copying and reproduction so long as the original work is given appropriate credit. Contents may not be used for commercial purposes, or adapted, remixed, transformed or built upon. (https://creativecommons.org/ licenses/by-nc-nd/4.0/)

Thieme Revinter Publicações Ltda., Rua do Matoso 170, Rio de Janeiro, RJ, CEP 20270-135, Brazil 


\section{Resumo}

\section{Palavras-chave \\ - neutropenia \\ - câncer colorretal \\ - polimorfismos}

in homozygosis or heterozygosis, presented higher risk of developing severe neutropenia than patients with the $6 / 6$ genotype (odds ratio $=1.559 ; 95 \%$ confidence interval $=1.163-2.090 ; p=0.003$ ).

Conclusion The analysis of the UGT1A $1^{*} 28$ gene polymorphism can aid the choice of treatment for patients with colorectal cancer in personalized medicine, increasing the chances of therapeutic success.

Objetivo Avaliar a relação do polimorfismo do gene UGT1A $1 * 28$ com a prevalência de neutropenia em pacientes com câncer colorretal submetidos a tratamento com o irinotecano.

Método Foram incluídos 13 estudos sobre o tema proposto, selecionados nas bases de dados da Biblioteca Virtual de Saúde, Scientific Electronic Library Online, International Health Sciences Literature e PubMed. Os dados foram coletados dos artigos científicos selecionados e avaliados com o auxílio do software BioEstat 5.3 (BioEstat, Belém, PA, Brasil).

Resultados Os genótipos analisados foram 6/6 (tipo selvagem), 6/7 e 7/7. Foram incluídos 2.146 pacientes. Destes, 55,6\% $(n=1.193)$ apresentaram genótipo $6 / 6,37,3 \%(n=801)$ eram heterozigotos (6/7) e 7,1\% ( $n=152)$ tinham o genótipo $7 / 7$. Um total de $1.672(77,9 \%)$ pacientes apresentou neutropenia leve e $474(22,1 \%)$ neutropenia severa. Ao contrastar os genótipos 6/7 e 7/7 com o 6/6, percebeu-se, com a execução dos testes estatísticos de metaanálise, que os pacientes com o alelo 7, em homozigose ou heterozigose, tinham maior risco de desenvolver neutropenia severa que pacientes com o genótipo 6/6 (razão de chances $=1,559$; intervalo de confiança de $95 \%=1,163-2,090 ; p=0,003$ ).

Conclusão A análise do polimorfismo do gene $U G T 1 A 1^{*} 28$ pode auxiliar na escolha do tratamento do paciente com câncer colorretal, no contexto da medicina personalizada, ampliando, assim, as chances de sucesso terapêutico.

\section{Introduction}

Colorectal cancer is the third most common type of neoplasm in men and the second most common in women; with the exception of non-melanoma skin cancer, it is the fourth main cause of cancer-related death worldwide. ${ }^{1}$ Many studies have been carried out all over the world in an attempt to improve colorectal cancer prevention, diagnosis, and treatment, with increasingly satisfactory outcomes. ${ }^{2}$

The heterogeneity of this condition challenges the choice of the best treatment for a patient because numerous factors interfere with therapeutic success. ${ }^{2}$ One of the most used chemotherapy agents is irinotecan, a topoisomerase I inhibitor with better therapeutic responses when compared with other drugs. ${ }^{3}$

The UGT1A1 gene encodes an enzyme called uridine-5'diphospho-glucoronosyltransferase (UGT), which inactivates and detoxifies SN-38, an active metabolite of irinotecan. Variations in UGT1A1 associated with reduced enzyme activity result in an increased level of active metabolites in the bloodstream, increasing the risk of neutropenia, that is, a reduced number of neutrophils, which is observed in some patients. ${ }^{4}$ These variations can affect the pharmacokinetics of therapeutic agents because they do not encode the enzymes playing a metabolic role, directly influencing the achievement of desired effects. ${ }^{5}$
An additional TA repeat in the TATA sequence of the UGT1A1 promoter region, which becomes (TA)7TAA instead of (TA) 6TAA, characterizes UGT1A1* 28 polymorphism. ${ }^{6}$ The Food and Drug Administration (FDA) states that patients who are homozygous for the UGT1A1*28 allele must receive $70 \%$ of the standard dose, gradually increasing according to neutrophil numbers. Heterozygous patients require no specific action. ${ }^{4}$

Advances in genetic studies and the greater knowledge regarding interactions between the patient's metabolism and the mechanism of action of chemotherapeutic substances will allow the use of an optimal drug, avoiding countless attempts to reach a specific treatment response. ${ }^{7}$

This study aimed to evaluate the relationship of the UGT1A1 28 gene polymorphism with the prevalence of neutropenia in patients with colorectal cancer treated with irinotecan.

\section{Method}

The present study was carried out from a systematic review of the literature, using original articles on the incidence of neutropenia in patients treated with irinotecan and with UGT1A1 28 gene polymorphisms. Through a meta-analysis methodology, studies were selected, and their data were extracted for statistical analysis, reducing the subjectivity from other review methods characterized as quantitative analyzes. $^{8}$ 


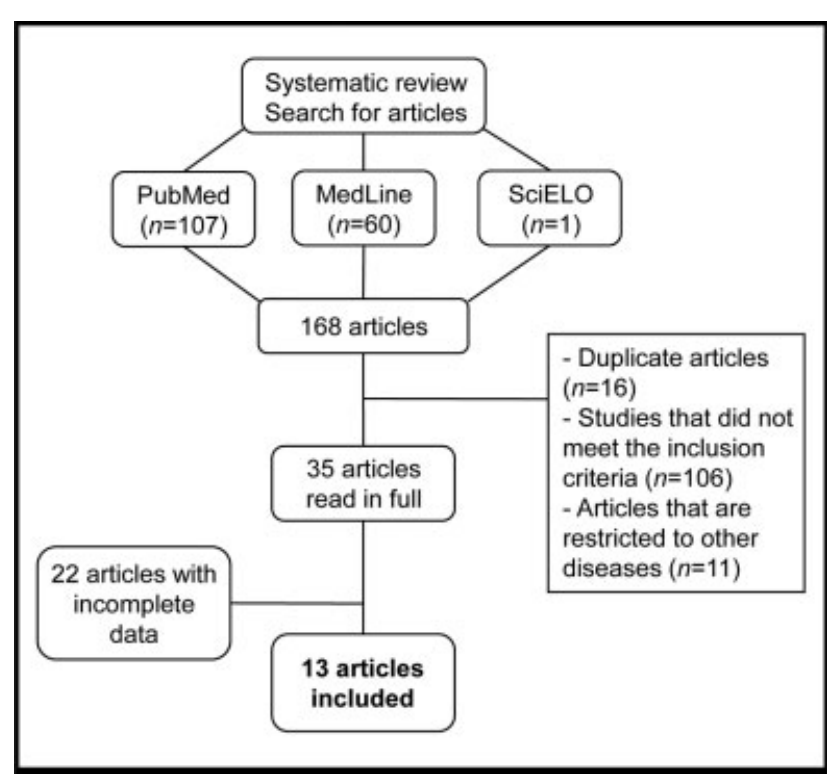

Fig. 1 Flowchart for paper selection.

Articles in Portuguese and English, published from 2007 to 2018, about UGT1A1 polymorphisms and irinotecan-induced neutropenia in colorectal cancer were included to highlight the importance of genetic polymorphisms studies and their contribution to therapeutic improvement. Articles that did not mention polymorphisms associated with colorectal cancer or genetic factors that could result in cancer were excluded. Studies published in languages and time periods other than those defined in the inclusion criteria were also excluded (-Figure 1).

The following databases were queried: Virtual Health Library (VHL, also known as Biblioteca Virtual em Saúde, BVS), Scientific Electronic Library Online (SciELO), International Health
Sciences Literature (Medline) and PubMed from the National Center for Biotechnology Information (NCBI). In addition to papers published between 2007 and 2018, other articles were used for theoretical support and discussion.

After information collection, studies selection, and results extraction, an analysis of the data associated common aspects between UGT1A1*28 gene polymorphism and irinotecaninduced neutropenia. Using the BioEstat 5.3 software (BioEstat, Belém, PA, Brazil), statistical tests for meta-analysis were applied to calculate the odds ratio (OR), 95\% confidence interval $(95 \% \mathrm{CI})$, and weight of each study and the combined sample. Significance was set at a $5 \%$ level.

\section{Results}

Data were collected from 13 studies, including a total of 2,146 patients, distributed as follows: 1,193 patients presented the 6/6 genotype, 801 were heterozygous, and 152 had the 7/7 genotype. Toxicity was classified as mild or severe neutropenia. Among patients treated with irinotecan, 1,672 (77.9\%) had mild neutropenia and $474(22.1 \%)$ presented severe neutropenia (-Table 1).

Contrasting $6 / 7$ and $7 / 7$ genotypes with the $6 / 6$ genotype resulted in an odds ratio of 1.559 with a 95\% confidence interval ranging from 1.1663 to 2.090 ( - Table 2; - Figure 2).

\section{Discussion}

Individual treatment warranted by genetic evidence is a widely accepted strategy, usually safe and with high chances of success. When evaluating polymorphisms and toxicity rates, we found a significant relationship between the 7 allele and the prevalence of severe neutropenia in patients with colorectal cancer treated with irinotecan.

Table 1 Severe neutropenia frequency per UGT1A $1^{*} 28$ genotype

\begin{tabular}{|c|c|c|c|c|c|c|c|c|c|}
\hline \multirow[t]{2}{*}{ Authors } & \multicolumn{3}{|l|}{$6 / 6$} & \multicolumn{3}{|l|}{$6 / 7$} & \multicolumn{3}{|l|}{$7 / 7$} \\
\hline & $n$ & SN & $f(\%)$ & $n$ & SN & $f(\%)$ & $n$ & SN & $f(\%)$ \\
\hline McLeod et al. ${ }^{9}$ & 44 & 3 & 6.8 & 54 & 6 & 11.1 & 11 & 2 & 18.2 \\
\hline Glimelius et al. ${ }^{10}$ & 72 & 15 & 20.8 & 51 & 13 & 25.5 & 13 & 7 & 53.8 \\
\hline Shulman et al. ${ }^{6}$ & 91 & 5 & 5.5 & 98 & 8 & 8.2 & 25 & 6 & 24.0 \\
\hline Braun et al. ${ }^{11}$ & 79 & 57 & 72.2 & 68 & 44 & 64.7 & 20 & 15 & 75.0 \\
\hline Toffoli et al. ${ }^{12}$ & 114 & 12 & 10.5 & 114 & 21 & 18.4 & 22 & 4 & 18.2 \\
\hline Kweekel et al. ${ }^{13}$ & 46 & 1 & 2.2 & 31 & 6 & 19.4 & 3 & 0 & 0.0 \\
\hline Ruzzo et al. ${ }^{14}$ & 59 & 9 & 15.3 & 72 & 13 & 18.1 & 15 & 12 & 80.0 \\
\hline Liu et al. ${ }^{15}$ & 501 & 90 & 18.0 & 152 & 42 & 27.6 & 8 & 4 & 50.0 \\
\hline Rouits et al. ${ }^{16}$ & 31 & 3 & 9.7 & 35 & 9 & 25.7 & 7 & 2 & 28.6 \\
\hline Carlini et al. ${ }^{17}$ & 28 & 10 & 35.7 & 29 & 11 & 37.9 & 5 & 0 & 0.0 \\
\hline Marcuello et al. ${ }^{18}$ & 40 & 6 & 15.0 & 45 & 12 & 26.7 & 10 & 4 & 40.0 \\
\hline Stewart et al. ${ }^{19}$ & 27 & 5 & 18.5 & 36 & 3 & 8.3 & 9 & 0 & 0.0 \\
\hline Bai et al. ${ }^{20}$ & 61 & 11 & 18.0 & 16 & 2 & 12.5 & 4 & 1 & 25.0 \\
\hline Combined values & 1,193 & 227 & 19.0 & 801 & 190 & 23.7 & 152 & 57 & 37.5 \\
\hline
\end{tabular}

Abbreviations: $f$, Frequency; $n$, sample size; SN, severe neutropenia. 
Table 2 Neutropenia-developing risk analysis per genotypes

\begin{tabular}{|c|c|c|c|c|c|c|c|c|c|c|c|c|c|c|}
\hline \multirow[t]{2}{*}{ Authors } & \multicolumn{5}{|l|}{$6 / 6$} & \multicolumn{5}{|c|}{$6 / 7+7 / 7$} & \multirow[t]{2}{*}{ OR } & \multicolumn{2}{|l|}{$\mathrm{Cl} 95 \%$} & \multirow[t]{2}{*}{ Weight } \\
\hline & $n$ & MN & $f(\%)$ & SN & $f(\%)$ & $n$ & $\mathrm{MN}$ & $f(\%)$ & SN & $f(\%)$ & & $\begin{array}{l}\text { Lower } \\
\text { value }\end{array}$ & $\begin{array}{l}\text { Upper } \\
\text { value }\end{array}$ & \\
\hline McLeod et al. ${ }^{9}$ & 44 & 41 & 93.2 & 3 & 6.8 & 65 & 57 & 87.7 & 8 & 12.3 & 1.753 & 0.474 & 6.478 & 2.25 \\
\hline Glimelius et al. $^{10}$ & 72 & 57 & 79.2 & 15 & 20.8 & 64 & 44 & 68.8 & 20 & 31.3 & 1.709 & 0.794 & 3.680 & 6.53 \\
\hline Shulman et al. $^{6}$ & 91 & 86 & 94.5 & 5 & 5.5 & 123 & 109 & 88.6 & 14 & 11.4 & 2.083 & 0.750 & 5.783 & 3.68 \\
\hline Braun et al. ${ }^{11}$ & 79 & 22 & 27.8 & 57 & 72.2 & 88 & 29 & 33.0 & 59 & 67.0 & 0.789 & 0.409 & 1.523 & 8.89 \\
\hline Toffoli et al. ${ }^{12}$ & 114 & 102 & 89.5 & 12 & 10.5 & 136 & 111 & 81.6 & 25 & 18.4 & 1.875 & 0.906 & 3.884 & 7.25 \\
\hline Kweekel et al. ${ }^{13}$ & 46 & 45 & 97.8 & 1 & 2.2 & 34 & 28 & 82.4 & 6 & 17.6 & 6.918 & 1.103 & 43.391 & 1.14 \\
\hline Ruzzo et al. ${ }^{14}$ & 59 & 50 & 84.7 & 9 & 15.3 & 87 & 62 & 71.3 & 25 & 28.7 & 2.169 & 0.944 & 4.985 & 5.55 \\
\hline Liu et al. ${ }^{15}$ & 501 & 411 & 82.0 & 90 & 18.0 & 160 & 114 & 71.3 & 46 & 28.8 & 1.847 & 1.226 & 2.782 & 22.87 \\
\hline Rouits et al. ${ }^{16}$ & 31 & 28 & 90.3 & 3 & 9.7 & 42 & 31 & 73.8 & 11 & 26.2 & 2.973 & 0.811 & 10.901 & 2.28 \\
\hline Carlini et al. ${ }^{17}$ & 28 & 18 & 64.3 & 10 & 35.7 & 34 & 23 & 67.6 & 11 & 32.4 & 0.862 & 0.306 & 2.427 & 3.59 \\
\hline Marcuello et al. ${ }^{18}$ & 40 & 34 & 85.0 & 6 & 15.0 & 55 & 39 & 70.9 & 16 & 29.1 & 2.217 & 0.803 & 6.125 & 3.72 \\
\hline Stewart et al. ${ }^{19}$ & 27 & 22 & 81.5 & 5 & 18.5 & 45 & 42 & 93.3 & 3 & 6.7 & 0.337 & 0.080 & 1.414 & 1.87 \\
\hline Bai et al. ${ }^{20}$ & 61 & 50 & 82.0 & 11 & 18.0 & 20 & 17 & 85.0 & 3 & 15.0 & 0.878 & 0.236 & 3.269 & 2.22 \\
\hline $\begin{array}{l}\text { Combined } \\
\text { values }\end{array}$ & 1193 & 966 & 81.0 & 227 & 19.0 & 953 & 706 & 74.1 & 247 & 25.9 & 1.559 & 1.163 & 2.090 & $p=0.003 c$ \\
\hline
\end{tabular}

Abbreviations: $\mathrm{Cl}$, Confidence interval; $f$, frequency; MN, mild neutropenia; $n$, sample size; OR, odds ratio; SN, severe neutropenia.

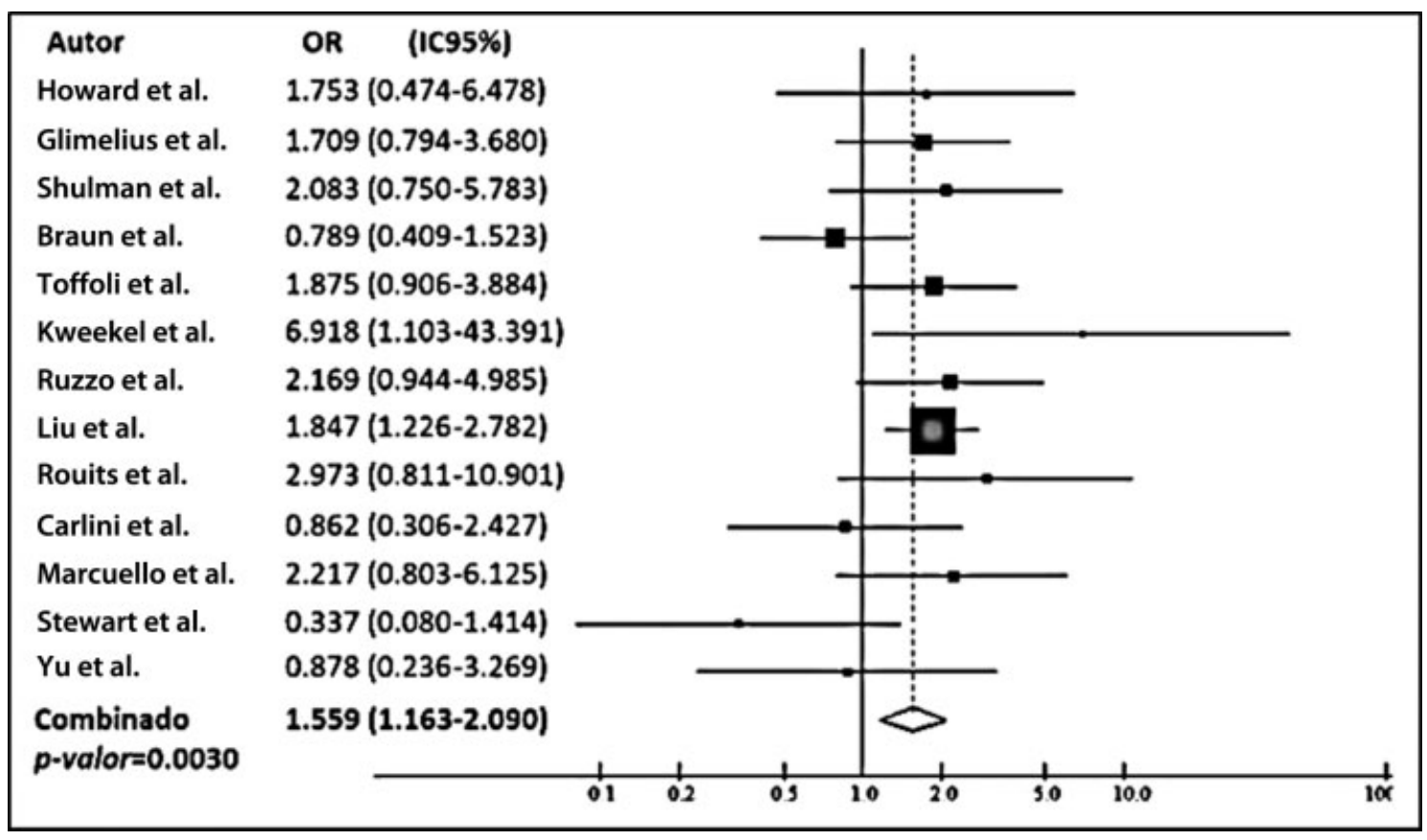

Fig. 2 Risk estimative for neutropenia development in patients with allele 7. Abbreviations: $\mathrm{Cl}$, confidence interval; OR, odds ratio.

At early therapy cycles, Toffoli et al. ${ }^{12}$ found a relevant association in patients with $7 / 7$ genotype to an increased risk for developing grade 3 or 4 neutropenia compared to patients with the 6/6 genotype. However, when evaluating the entire treatment cycle, no significant association with hematological and non-hematological toxicities was detected. Similar results were found by Braun, ${ }^{11}$ who identified the influence of polymorphism only during the first 12 weeks of therapy.
Comparing patients with $6 / 6$ and 6/7 genotypes, Rouits et al. $^{16}$ found a higher frequency of severe neutropenia in patients homozygotic for the 7 allele. These authors also analyzed the risk of developing diarrhea, in which the genotype was not so influent as in neutropenia. When evaluating the relationship among polymorphism, neutropenia prevalence and chemotherapeutic agent dose in homozygous patients, reduced dosages resulted in no significant improvement. 
Similar to the findings of our study, Côté et al. ${ }^{21}$ found a significant influence from the UGT1A1*28 polymorphism but highlighted the $-3156 G>A$ polymorphism to better predict irinotecan toxicity during treatment. In addition, these authors recommend an up to $50 \%$ dose reduction in subjects with the 7 allele, especially homozygotes, resulting in lower toxicity and better therapeutic outcomes. However, information and studies on effective doses and which ones would lead to less toxic effects are scarce. There are few clinical studies on doses tailored by the patient's genotype and the presence of severe or mild neutropenia. An optimal scenario would be to evaluate the genetic polymorphism profile before chemotherapy institution to avoid exposure to severe toxicities that weaken the patient. Individualized treatments with accurate effectiveness are the goals of personalized medicine, using means, including genetic methods, to outline the best form of therapy while minimizing or abolishing toxicity.

\section{Conclusion}

The presence of the 7 allele increased the chance of severe neutropenia at approximately 1.5 -fold in patients with colorectal cancer treated with irinotecan. Since an association with severe neutropenia was detected, chemotherapeutic agent pharmacokinetics and the genes involved in their metabolism must be studied in more details to find other types of polymorphisms in different genes.

\section{Conflict of Interests}

The authors declare that there is no conflict of interests regarding the publication of this article.

\section{References}

1 INCA. Incidência de Câncer no Brasil. 2018

2 Junqueira MZ, Chammas R. Cancer chemotherapy failure: a synthetic view. Rev Med (São Paulo) 2018;97(02):1-3

3 Liu X, Cheng D, Kuang Q Liu G, Xu W. Association of UGT1A1*28 polymorphisms with irinotecan-induced toxicities in colorectal cancer: a meta-analysis in Caucasians. Pharmacogenomics J 2014; 14(02):120-129

4 Dean L. Irinotecan Therapy and UGT1A1 Genotype Drug: Irinotecan. 2009;(Md)1-8

5 Brockmöller J, Tzvetkov MV. Pharmacogenetics: data, concepts and tools to improve drug discovery and drug treatment. Eur J Clin Pharmacol 2008;64(02):133-157

6 Shulman K, Cohen I, Barnett-Griness O, et al. Colorectal Cancer Patients. 2012;117(14):3156-3162

7 Nakanishi M. Precision medicine. Rev Bras Otorrinolaringol (Engl Ed) $2018 ; 84(03): 263-264$
8 dos Santos EJF, Cunha M. Interpretação crítica dos resultados estatísticos de uma meta-análise: estratégias metodológicas. Millenium. 2013;44:85-98

9 McLeod HL, Sargent DJ, Marsh S, et al. Pharmacogenetic predictors of adverse events and response to chemotherapy in metastatic colorectal cancer: results from North American Gastrointestinal Intergroup Trial N9741. J Clin Oncol 2010;28(20):3227-3233

10 Glimelius B, Garmo H, Berglund A, et al. Prediction of irinotecan and 5-fluorouracil toxicity and response in patients with advanced colorectal cancer. Pharmacogenomics J 2011;11(01): 61-71

11 Braun MS, Richman SD, Thompson L, et al. Association of molecular markers with toxicity outcomes in a randomized trial of chemotherapy for advanced colorectal cancer: the FOCUS trial. J Clin Oncol 2009;27(33):5519-5528

12 Toffoli G, Cecchin E, Corona G, et al. The role of UGT1A1*28 polymorphism in the pharmacodynamics and pharmacokinetics of irinotecan in patients with metastatic colorectal cancer. J Clin Oncol 2006;24(19):3061-3068

13 Kweekel DM, Gelderblom H, Van der Straaten T, Antonini NF, Punt CJA, Guchelaar HJDutch Colorectal Cancer Group study. UGT1A $1 * 28$ genotype and irinotecan dosage in patients with metastatic colorectal cancer: a Dutch Colorectal Cancer Group study. Br J Cancer 2008;99(02):275-282

14 Ruzzo A, Graziano F, Loupakis F, et al. Pharmacogenetic profiling in patients with advanced colorectal cancer treated with firstline FOLFIRI chemotherapy. Pharmacogenomics J 2008;8(04): 278-288

15 Liu D, Li J, Gao J, Li Y, Yang R, Shen L. Examination of multiple UGT1A and DPYD polymorphisms has limited ability to predict the toxicity and efficacy of metastatic colorectal cancer treated with irinotecan-based chemotherapy: a retrospective analysis. BMC Cancer 2017; 17(01):437

16 Rouits E, Boisdron-Celle M, Dumont A, Guérin O, Morel A, Gamelin E. Relevance of different UGT1A1 polymorphisms in irinotecaninduced toxicity: a molecular and clinical study of 75 patients. Clin Cancer Res 2004;10(15):5151-5159

17 Carlini LE, Meropol NJ, Bever J, et al. UGT1A7 and UGT1A9 polymorphisms predict response and toxicity in colorectal cancer patients treated with capecitabine/irinotecan. Clin Cancer Res 2005;11(03):1226-1236

18 Marcuello E, Altés A, Menoyo A, Del Rio E, Gómez-Pardo M, Baiget M. UGT1A1 gene variations and irinotecan treatment in patients with metastatic colorectal cancer. Br J Cancer 2004;91(04): 678-682

19 Stewart CF, Panetta JC, O'Shaughnessy MA, et al. UGT1A1 promoter genotype correlates with SN-38 pharmacokinetics, but not severe toxicity in patients receiving low-dose irinotecan. J Clin Oncol 2007;25(18):2594-2600

20 Bai Y, Wu HW, Ma X, Liu Y, Zhang YH. Relationship between UGT1A $1^{*} 6 /{ }^{*} 28$ gene polymorphisms and the efficacy and toxicity of irinotecan-based chemotherapy. OncoTargets Ther 2017; 10:3071-3081

21 Côté JF, Kirzin S, Kramar A, et al. UGT1A1 polymorphism can predict hematologic toxicity in patients treated with irinotecan. Clin Cancer Res 2007;13(11):3269-3275 